\title{
Indiens energiutmaningar
}

\author{
HANS BLOMKVIST \\ Uppsala universitet
}

\begin{abstract}
36
Indien och Kina håller i rask takt på att bli globala jättar. Med en ekonomisk tillväxt runt 10 procent per år under de senaste ett till två decennierna börjar de påverka resten av världen på ett högst påtagligt sätt, inte minst på energiområdet. Artikeln analyserar dagens energiförsörjning i Indien samt IEA:s antaganden om situationen det närmaste decenniet. Indiens ökande användning och import av fossila bränslen, ökande utsläpp av växthusgaser samt den mycket ojämnt fördelade energianvändningen diskuteras. Några av de främsta problemen dryftas i artikeln: subsidier eller ibland gratis elektricitet till jordbruket; den stora fattigdomen; samt den mjuka staten och korruptionen. Två av Indiens styrkor inför de kommande energiutmaningarna lyfts fram i artikeln. Dels betonas den höga nivån på ingenjörsvetenskapen som är central för utvecklandet av förnybar energi, dels de demokratiska institutionerna som möjliggör politiskt deltagande och påverkan på energi- och klimatfrågan.
\end{abstract}

Indien och Kina håller i rask takt på att bli globala jättar. ${ }^{1}$ Befolkningsmässigt är de sedan länge jättar. En tredjedel av hela världens befolkning bor i dessa två asiatiska länder. Med en ekonomisk tillväxt runt 10 procent per år under de senaste ett till två decennierna börjar de påverka resten av världen på ett högst påtagligt sätt. Och förmodligen har vi bara sett början på denna utveckling. År 2050, spår en prognos (av Pricewaterhouse), kommer Indiens ekonomi att vara lika stor som USAs och Kinas vara nästan en och en halv gång så stor som den amerikanska (när man kontrollerar för köpkraft, PPP).

Jag vill tacka för synpunkter som framfördes vid ett seminarium om «Indiens utfordringer» vid Universitetet i Oslo i mars 2007, arrangerat av professor Arild Engelsen Ruud, samt från två anonyma reviewers som givit omfattande och värdefulla synpunkter på en tidigare version av denna text.

1 Artikeln är skriven inom ett forskningsprogram vid Uppsala universitet om institutioner och politiskt beslutsfattande kring bioenergi i Indien och EU, finansierat av den statliga Energimyndigheten under perioden 2007-2011. Förutom Blomkvist ingår Roland Roberts, professor i geofysik, och Katrin Uba, dr i statsvetenskap. 
Hur kommer en fortsatt ekonomisk tillväxt att påverka energibehovet i Indien? Och hur kommer en ökad indisk energikonsumtion att påverka energiresurser och klimat i Indien och resten av världen? Vilka politiska förutsättningar har Indien att leva upp till dessa utmaningar? Det är dessa frågor, och framför allt den sista, jag ska försöka ta mig an i denna artikel. En svårighet med detta är uppenbar: det handlar om framtiden, om prognoser och därmed om gissningar. Men genom att jämföra dagens energikonsumtion i Indien med den i Europa och andra OECD-länder får vi ändå en grund för en ganska god gissning om framtida energibehov. Anledningen till detta är att det finns ett mycket starkt samband mellan energikonsumtion och ekonomisk utveckling (BNP per capita), både mellan länder och för utvecklingen i Indien (Elias \& Victor 2005, fig. 1 och 2). En ökad industrialisering, mekanisering av jordbruket och ökad levnadsstandard kommer samtliga att ställa ökade krav på energiproduktion i Indien.

Artikeln analyserar dagens energiförsörjning i Indien samt antaganden om situationen det närmaste decenniet. Med hjälp av dessa data från OECDorganet IEA visar artikeln hur Indiens ökande användning och import av fossila bränslen, ökande utsläpp av växthusgaser kommer att påverka de globala energiförutsättningarna. Sen lyfter jag fram några av de främsta utmaningarna Indien står inför i att bemästra denna situation: den nästan försumbara andelen förnyelsebar energi, den mycket ojämnt fördelade energianvändningen (hälften av indiska hushåll saknar elektricitet), subsidier eller ibland gratis elektricitet till jordbruket, samt den mjuka staten och korruptionen. Två av Indiens styrkor inför de kommande energiutmaningarna lyfts fram i artikeln. Dels betonas den höga nivån på ingenjörsvetenskapen som är central för utvecklandet av förnyelsebar energi, dels de demokratiska institutionerna som möjliggör politiskt deltagande och påverkan på energioch klimatfrågan.

\section{Energiförsörjning globalt och i Indien}

«Tillgången på vatten, mat och energi» är de tre mest centrala utmaningarna för vår överlevnad, hävdade den indiske premiärministern Manmohan Singh i början av 2007 (The Hindu, 4 jan.). Genomsnittligt konsumerar vi i den rika världen ca tio gånger så mycket energi per person som de gör i Indien. Lite mer precist konsumerade vi (innevånarna i IEAs, International Energy Agency, medlemsländer) 5,15 toe (tonne oil equivalent, det jämförelsemått som används) per person och indierna 0,55 toe per person år 2004 (IEA 2006a: 518, IEA 2006b: 342). Indiern konsumerade 435 kilowattimmar $(\mathrm{kWh})$ elektricitet år 2003 medan genomsnittet $\mathrm{i}$ världen låg på ca 2500 kWh (Chen et al. 2007: 2614). 


\section{Tabell I: Energiåtgång i Mtoe (miljoner ton oljeekvivalent) och CO2-utsläpp (miljoner ton)}

\begin{tabular}{r|r|r|r|r|r|r} 
& $\begin{array}{c}\text { Energi- } \\
\text { åtgång } \\
2004\end{array}$ & $\begin{array}{c}\text { Energi- } \\
\text { åtgång } \\
2015\end{array}$ & $\begin{array}{r}\text { Energi- } \\
\text { okning,\% } \\
\text { per år } \\
2004-2015\end{array}$ & $\begin{array}{c}\text { CO2- } \\
\text { utsläpp } \\
2004\end{array}$ & $\begin{array}{c}\text { CO2- } \\
\text { utsläpp } \\
2015\end{array}$ & $\begin{array}{c}\text { CO2-utsläpps- } \\
\text { ökning, \% } \\
\text { per år } \\
2004-2015\end{array}$ \\
\hline Världen & 11.000 & 14.000 & 2,1 & 26.000 & 33.000 & 2,3 \\
OECD & 5.500 & 6.300 & 1,2 & 13.000 & 14.000 & 1,1 \\
USA & 2.300 & 2.700 & 1,2 & 6.000 & 7.000 & 1,2 \\
EU & 1.800 & 1.900 & 0,7 & 4.000 & 4.000 & 0,5 \\
Utvecklingsländer & 4.500 & 6.400 & 3,3 & 10.000 & 15.000 & 3,8 \\
Kina & 1.600 & 2.500 & 4,0 & 5.000 & 8.000 & 4,5 \\
Brasilien & 200 & 300 & 2,6 & 300 & 400 & 2,2 \\
Indien & 600 & 800 & 2,8 & 1,000 & $\mathbf{1 6 0 0}$ & 3,6
\end{tabular}

Notera att de absoluta siffrorna är avrundade till jämnt hundratal eller tusental. Källa: International Energy Agency World Energy Outlook, 2006. ${ }^{2}$

Siffrorna i tabell 1 säger en hel del om energi- och klimatsituationen i världen de närmaste åren. Exakt hälften av världens energi konsumeras idag (2004) av den rika världen, den minoritet på drygt en miljard människor som bor i OECD-länderna. Vi släpper också ut precis hälften av $\mathrm{CO}_{2}$. Men om åtta år, 2015, beräknar IEA att OECDs andel av den globala energianvändningen har minskat till $45 \%$ medan utvecklingsländernas andel ökat från 40 till 45 \% (Ryssland och de så kallade transitionsekonomierna konsumerar återstoden). Kina, Indien och Brasilien - de tre snabbväxande stormakterna i Tredje världen - konsumerar idag drygt en femtedel av världens energi. 2015 beräknas de använda drygt en fjärdedel av energiresurserna. Dessa tre länders koldioxidutsläpp beräknas öka snabbare - från en fjärdedel av de globala utsläppen 2004 till nära en tredjedel (30 \%) år 2015.

När vi diskuterar det globala klimatet och det politiska och moraliska ansvar de olika siffrorna implicerar får vi inte i hastigheten glömma bort det enkla faktum att det bor ungefär fem gånger så många människor i utvecklingsländerna som i den rika (OECD) världen. Med andra ord så producerar vi i den rika världen drygt fem gånger så mycket $\mathrm{CO}_{2}$-utsläpp per person som människor i utvecklingsländer: 10.000 ton per person och år jämfört med knappt 2.000 ton per person och år. Jämför man ett par av extremerna

2 IEA är en oberoende organisation som skapades av OECD 1974. Deras data om energiproduktion och -konsumtion publiceras årligen och är de siffror som används av i stort sett alla bedömare och aktörer. Även om man alltid bör ta all information med en nypa salt så känner jag inte till någon stark kritik mot IEAs siffror. 
- USA och Indien - blir skillnaderna per capita ännu mer accentuerade. Som så ofta är det mer än en sanning vi måste hålla i huvudet samtidigt. Det stämmer naturligtvis, som bland andra europeiska politiker påpekat, att klimatpåverkan från de båda miljardländerna Indien och Kina i en snar framtid kommer att bli mycket stora i absoluta tal. Men det stämmer också att ekonomierna och medborgarna i OECD-länderna använder mer energi och har en större klimatpåverkan relativt sin folkmängd.

Under perioden 2004-2015 beräknas utvecklingsländerna öka sitt energibehov fyra till fem gånger snabbare än EU och koldioxidutsläppen i en ännu snabbare takt. Denna dubbla globala utmaning av snabbt ökande energibehov hos de fem miljarder som lever i utvecklingsländer och därmed påföljande hot mot vårt gemensamma klimat har ställt oss inför nya frågor och uppgifter. Premiärminister Manmohan Singh formulerade det så här vid en indisk vetenskaplig kongress i början av 2007:

We can and must use the inventiveness and ingenuity of our knowledge to find new paths to growth. But this must be a shared effort. It must be an effort that enables the poor to improve their quality of life, their well-being, their consumption levels, without being forced to pay the price for the profligacy and excessive consumption of the rich and the super rich. The developing world cannot accept a freeze on global inequity (The Hindu 4 jan., min kurs.).

Av Indiens totala energitillförseln kommer Go procent från fossila bränslen - kol, olja och gas - och i stort sett hela återstoden från biomassa och avfall (främst traditionell användning). Andra förnyelsebara energikällor motsvarar inte ens en hundradel. I jämförelse med energiförsörjningen globalt och i flera andra delar av världen kommer en stor andel i Indien från biomassa och avfall (se tabell 2). Indien har stora egna kolreserver. Däremot kommer det ökande behovet av olja och gas att till stor del behöva importeras. IEA (2006a) bedömer att Indien kommer att öka sin oljekonsumtion med 45 $\%$ och sin gaskonsumtion med hela $74 \%$ under perioden 2004-2015. En sådan ökning kommer naturligtvis att påverka priset på olja och gas och därmed resten av världen.

År 2006 var den samlade konsumtionen av olja i Indien 2,6 miljoner fat om dagen. Av detta importerades 1,8 miljoner fat eller nära $70 \%$, varav hälften importeras från Mellanöstern. Den inhemska oljeutvinningen sker framför allt i havet utanför Mumbai (Bombay) och i nordöst, men stora reserver finns i Bengaliska viken och i Rajasthan i västra Indien (EIA 2007). Det statligt ägda Oil and Natural Gas Corporation (ONGC) är landets största oljeföretag. ONGC har också intressen i utomlands i 15 olika länder, däribland Sudan och Ryssland. De kända gasreserverna i Indien uppgår till 30 trillioner kubikfot. Landet importerar mindre mängder med 
Tabell 2: Energiförsörjning i procent, 2004

\begin{tabular}{r|c|c|c|c|c|c|c} 
& Kol & Olja & Gas & $\begin{array}{c}\text { Kärn- } \\
\text { kraft }\end{array}$ & $\begin{array}{c}\text { Vatten- } \\
\text { kraft }\end{array}$ & $\begin{array}{c}\text { Biomassa } \\
\text { och avfall }\end{array}$ & $\begin{array}{c}\text { Andra förny- } \\
\text { bara källor }\end{array}$ \\
\hline Världen & 25 & 35 & 21 & 21 & 6 & 10 & 1 \\
OECD & 21 & 41 & 22 & 22 & 11 & 3 & 1 \\
USA & 23 & 41 & 22 & 22 & 9 & 3 & $\circ$ \\
Europa & 18 & 38 & 24 & 24 & 14 & 4 & 1 \\
Utvecklingsländer & 32 & 30 & 13 & 13 & 1 & 22 & $\circ$ \\
Kina & 61 & 20 & 3 & 3 & 1 & 14 & $\circ$ \\
Brasilien & 14 & 85 & 16 & 16 & 3 & 54 & $\circ$ \\
Indien & 34 & $\mathbf{2 2}$ & 4 & 4 & $\mathbf{I}$ & 37 & $\circ$
\end{tabular}

Källa: International Energy Agency World Energy Outlook, 2006.

gas. Importbehovet väntas öka varför det finns diskussioner och planer om gasledningar från flera grannländer. Sen 1994 har diskussioner förts med Pakistan och Iran om en gasledning från det senare landet. Men dessa förhandlingar strandade i slutet av 2006 på grund av oenighet om priset samt Indiens krav om säkerhetsgarantier för ledningen genom Pakistan (ibid.). I början av 2006 inbjöds Indien till den så kallade Trans-afghanska gasledningen som är tänkt att förbinda gasfält i Turkmenistan med Afghanistan och Pakistan och möjligen Indien. Av lätt förståeliga skäl har den indiska regeringen varit tveksam om säkerheten för en sådan gasledning. I mars 2006 undertecknade regeringarna i Indien och Myanmar (Burma) ett kontrakt om gasleveranser. Men än finns ingen gasledning. Planen var först att dra en ledning genom Bangladesh, men nu verkar tanken vara att dra den direkt från Myanmar till Indien (ibid.). I januari 2006 slöt Indien och Kina ett avtal om ökat samarbete inom gas- och oljesektorn, «Memorandum for Enhancing Cooperation in the Field of Oil and Natural Gas». Överenskommelsen gick ut på informationsutbyte inför ett möjligt köp i tredje land, en möjlig kartell helt enkelt.

Den indiska ekonomin spås att fortsätta växa kraftigt liksom energibehovet som förväntas öka med 2,8 \% årligen under perioden 2004 till 2015. Motsvarande siffra för OECD är 1,2 \% och för Europa o,8 \% (IEA 2006a: 518 , 494, 504). Föga förvånande visar forskning att det finns ett starkt samband mellan ekonomisk utveckling och energikonsumtion. Tillgången på elektricitet i Indien har årligen ökat med imponerande 8,7 \% sen 1960-talet (Thakur et al. 2006: 2788). Men behoven och utmaningarna är enorma. Fyra av tio hushåll saknar idag elektricitet (MoP 2007). På landsbygden saknar en majoritet (55\%) av hushållen elektricitet (Srivastava \& Rehman 2006: 645), i städerna ca $12 \%$ (Kale 2004: 468). Annorlunda formulerat: av de 
Tabell 3: Energikällor för elproduktionen i Indien, 2004 och 2015 i procent samt ökning

\begin{tabular}{|c|c|c|c|c|c|c|c|c|c|c|}
\hline & Kol & Olja & Gas & $\begin{array}{c}\text { Atom- } \\
\text { kraft }\end{array}$ & $\begin{array}{c}\text { Vatten- } \\
\text { kraft }\end{array}$ & $\begin{array}{l}\text { Biomassa } \\
\text { och avfall }\end{array}$ & Vind & $\begin{array}{c}\text { Geo- } \\
\text { termisk }\end{array}$ & Sol & $\begin{array}{l}\text { Våg- } \\
\text { kraft }\end{array}$ \\
\hline 2004 & 69 & 5 & 9 & 3 & 3 & 0 & 1 & 0 & o & 0 \\
\hline 2015 & 68 & 4 & 8 & 6 & 6 & 1 & 1 & o & ० & 0 \\
\hline $\begin{array}{l}\text { Årlig ökning } \\
2004-2015, \%\end{array}$ & 5.6 & 2.8 & 4.1 & 13.8 & 13.8 & 20.6 & 15.3 & - & 23.4 & \\
\hline
\end{tabular}

Källa: International Energy Agency World Energy Outlook, 2006.

ca 1,5 miljard människor i världen som saknar elektricitet bor en tredjedel i Indien. Och det är nästan uteslutande de fattigaste som saknar elektricitet. Inte bara de fattigaste utan även den moderna industrin drabbas av energibrist och elavbrott (Gulyani 1999).

De fattiga hushållen eldar med ved, växtavfall och avföring från kor vid matlagning (och uppvärmning under den kalla årstiden i norra Indien). Sådan biomassa utgör den största enskilda energikällan i Indien (jfr tabell 2). Den absoluta merparten av energianvändning från biomassa sker «traditionellt». Denna traditionella energianvändning är ofta mycket tidskrävande, ett arbete som ofta kvinnor och barn utför, dessutom hälsovådlig (Mathur \& Mathur 2005) och energimässigt ineffektiv. En del av de rikare hushållen har elspis, men många använder gas i köket. Det förekommer en del forskning i Indien för att utveckla och förbättra vedugnar och användningen av biomassa i hushållen (t ex vid Indian Institute of Science i Bangalore). Att omvandla energin i biomassa till ånga eller elektricitet uppgår till en betydligt mer blygsam omfattning, ca $300 \mathrm{MW}$ (megawatt). Tabell 3 visar från vilka källor elektricitet producerades 2004 samt prognosen för 2015 .

OECD-organet IEA (2006a) bedömer att Indiens energianvändning kommer att förändras en del de närmaste decennierna. Prognosen är att landet 2015 kommer att öka användningen av fossila bränslen, kol olja och gas, från $60 \%$ (2004) till 65\%, fördubbla användningen av kärnkraft och vattenkraft från 2 till $4 \%$ och samtidigt minska användningen av biomassa till $30 \%$. Sett utifrån klimathotet är bilden ännu mörkare år 2030. Om drygt 20 år bedömer IEA att Indien till drygt $70 \%$ kommer att vara beroende av fossila bränslen medan biomassa gått ner ytterligare, till 23\%. Man räknar med att kärnkraften då står för $3 \%$ och vattenkraften för $2 \%$ av energiförsörjningen. Även om IEA:s prognos kan vara i konservativaste laget bör vi ha dagens siffror i åtanke när vi diskuterar utsikterna och nödvändigheten 
av förnybar energi: utöver den enda procent som utvinns ur vattenkraft och «traditionella» användningen av ved, avfall, koavföring etc så kommer i stort sett ingen energi från förnybara källor idag.

För att summera: Indien använder idag (2004) ungefär en tiondel så mycket energi per person som vi gör i de rika OECD-länderna. Under perioden 2004-2015 beräknas Indien öka sin energianvändning med 25 \% och CO2-utsläppen med 60\%. Detta kan jämföras med motsvarande ökning i OECD-länderna med 15 respektive $8 \%$. Endast ungefär hälften av alla indiska hushåll har idag elektricitet. Ökande politiska krav och ekonomisk efterfrågan av elektrifiering i hushåll, jordbruk och industri inte minst på grund av den mycket snabba ekonomiska tillväxten kommer att öka energianvändningen. Fortsatt urbanisering och en höjd levnadsstandard hos en växande medelklass ökar antalet bilar och därmed åtgången på bensin. Det är högst sannolikt att alla dessa faktorer kommer att starkt öka Indiens efterfrågan på utländsk olja och gas samt exploatering av landets stora inhemska kolreserver. Med andra ord - om trenderna håller i sig kommer miljardlandet att påverka både världsmarknadspriserna på olja och gas samt vårt gemensamma klimat. Men finns det inte lösningar inom förnybar energi? Har inte Indien förutsättningar att utveckla energi från vatten, biomassa och sol?

\section{Förnybar energi}

Indien har ända sedan 1970-talet utvecklat och haft ambitionen att i större skala använda förnybar energi. 1982 initierade det nationella Department of Non-conventional Energy Sources, som tio år senare omvandlades till ett fullvärdigt ministerium - enligt uppgift det enda ministeriet i världen för förnybar energi. Olika policyinstrument som subventionerade lån, skattelindring, tullsänkningar ledde till att landet i slutet av 9o-talet hade världens största solenergiprogram, det näst största biogasprogrammet och det fjärde största vindenergiprogrammet (Ghosh et al. 2002: 484). Men som framgår av tabell 3 , har dessa program ännu inte fătt genomslag i den kommersiella användningen av energi i Indien. En av anledningarna till detta, menar Ghosh et al., är att man inte «internaliserat de socioekonomiska externaliteterna» hos de konventionella energislagen - annorlunda uttryckt: de senare behöver inte betala för sin miljöpåverkan.

En diskussion som förs i Indien är vad dessa nya, eller icke-konventionella, energikällor kan betyda för avlägsna byar på landsbygden. Kan man elektrifiera utan att bygga kraftledningar? Ett exempel kan vara «mini-vattenkraftverk» (small hydro power) med kapacitet upp till 25 MW. Sådana har installerats inte minst $\mathrm{i}$ avlägsna bergsbyar. 
Solenergin motsvarar idag endast ca $2,5 \%$ av den förnyelsebara energin i Indien (ibid.: 488). En av de större anläggningarna finns utanför Jodhpur i Rajasthan. Problemet med solenergi är helt enkelt kostnaden. Att utvinna elektricitet från solen kostar idag ungefär tio gånger så mycket som utvinning från kol. Ministeriet för icke-konventionell energi nämner också, mycket kort, andra förnyelsebara energikällor som tidvatten, vågkraft, bergvärme, geotermisk energi från havet (ocean thermal energy) men konstaterar att dessa befinner sig på experimentstadiet (MNES 2005: 46). Idag finns installerad kapacitet från förnyelsebar energi motsvarande drygt $6000 \mathrm{MW}$ eller knappt $5 \%$ av Indiens elproduktion. Den förnybara energin kommer från vind, sol och biomassa. Vind genererade (2002) $1300 \mathrm{MW}$ (Ghosh et al. 2002: 486) eller motsvarande endast $0,03 \%$ av landets energiproduktion (MNES 2005: 41). Vindkraftverk finns framför allt i den södra delstaten Tamil Nadu. Potentialen för vindkraft har uppskattats till mångfalt mer än man nu utvinner.

Omvandlingen av biomassa till biobränslen eller i elproduktion har diskuterats starkt de senaste åren som en lösning på världens energiproblem (risken att oljan tar slut, «peak oil») och klimatförändringen (Sagar \& Kartha 2007). I Brasilien omvandlas sockerrör till etanol, i USA likaså samt delvis med hjälp av import av majs från Mexico. I Indien används framför allt sockerrör och jatropa-plantan för att utvinna biogas (Pachauri 2006: ix). Men några av flaskhalsarna för att kunna utvinna biomassa i större skala är tillgången på mark för odling samt att kunna synkronisera energiproduktionen med elnätet. Även om ordet bioenergi signalerar miljömedvetenhet så finns åtminstone ett par problem med detta energislag. Odling av grödor för energianvändning innebär flera risker. Den kan konkurrera med matproduktion; den amerikanska importen av majs från Mexico har höjt priset på tortillas så mycket att det ledde till demonstrationer. Odling av energigrödor kan också tvinga (ofta fattiga) människor att flytta från sin mark. Det finns också en oro att stora plantager med en enda gröda kan orsaka ekologiska problem. Det andra problemet är att även bioenergi, likt fossila bränslen, framkallar koldioxid vid förbränning. Denna förbränning räknas som klimatneutral eftersom växter tar upp koldioxid. Den förbränning som nu sker i Indien av biomassa och avfall - landets idag största energikälla - kan effektiviseras betydligt genom moderna förbränningsmetoder. Men lika fullt kommer förbränningen att producera $\mathrm{CO}_{2}$. Debatten om de globala energiproblemen ger intryck av att många har blandat ihop två olika problem: «peak oil» och klimatförändringen. Bioenergi kan vara en lösning på det förra men bara en dellösning på det senare problemet. 


\section{Jordbruket storkonsument av elektricitet}

Användningen av elektricitet i Indien förväntas öka med hela 5,7 \% per år under perioden 2004-2015 (IEA 2006a; motsvarande siffra för OECD är 1,7 \%). De nationella statliga offentliga utgifterna i Indien för elkraft utgjorde under 1990talet en tämligen stor andel (årligen varierande mellan 13 och 19\%; Sharma et al. 2005: 569). Trots detta hade man i början av 90-talet ett elunderskott på ca $8 \%$ och närmare $20 \%$ vid hög beläggning på nätet. Alla som varit i Indien känner väl till begreppen «power cut» och «load shedding» - den stund på kvällen när alla lampor slocknar och kylskåpet och tv-apparaten tystnar.

Som framgår av tabell 4 har jordbrukets andel av elkonsumtionen stadigt ökat sen 1950-talet. Det indiska jordbruket använder idag nästan en tredjedel av all elektricitet, vilket kanske inte ska förvåna i ett land där majoriteten lever av jordbruk. Däremot kanske det är förvånande att lantbrukarna betalar endast $5 \%$ av landets elräkning (Tongia 2003: 21).

Elektrifieringen av jordbruket skall förstås dels mot den historiska bakgrunden av de hungerkatastrofer som drabbade Indien på 1950- och 6o-talen. Dessa ledde till en mycket stor satsning på den Gröna revolutionen där elektrisk mekanisering av bevattningen var en viktig komponent. Dels har bönderna sedan dess skaffat sig en allt starkare position politiskt. Denna maktposition har kunnat utväxlas mot subsidier till jordbruket, inklusive billigare elektricitet. Ett uttryck för detta är att hela $87 \%$ av alla byar i Indien har elektricitet medan däremot endast $45 \%$ av landsbygdens hushåll är elektrifierade. Med andra ord, i tusentals byar runt om i landet är det endast de rikare husen och familjerna som har elektricitet. De fattiga får klara sig utan. Ibland har politikers vallöften till och med gått ut på att leverera elektricitet helt gratis till jordbruket (Tongia 2003: 22). Stödet till jordbruket från State Electricity Boards beräknades 2003 till 270 miljarder

\section{Tabell 4: Elproduktion och -konsumtion i Indien 1950-2000}

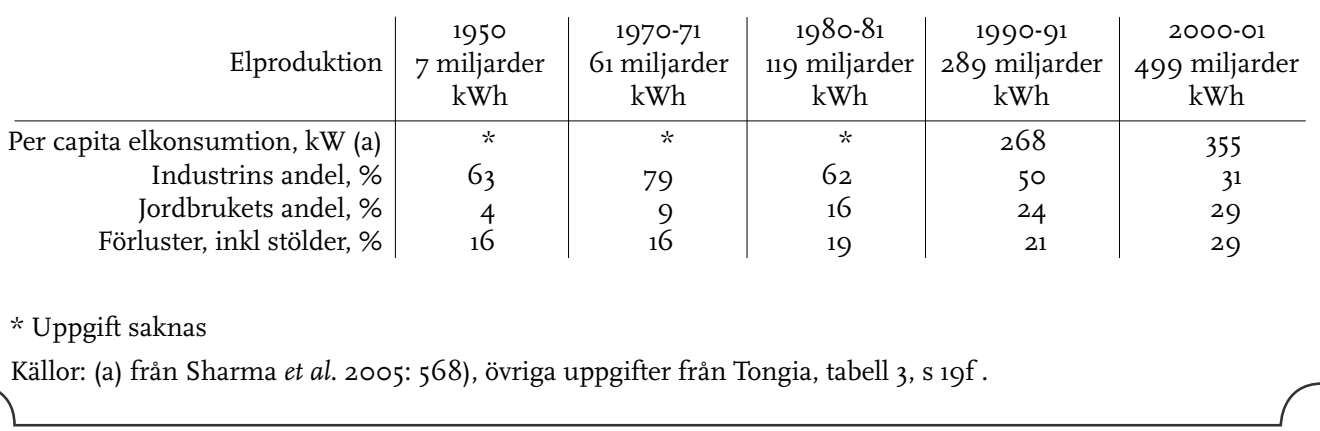


rupier, eller 43 miljarder svenska kronor (ibid.: 26). Rahul Tongia kallar det indiska jordbruket för «energisystemets undergång». I Andhra Pradesh, exempelvis, uppgick det statliga stödet till elektricitet $\mathrm{i}$ jordbruket till $2 \%$ av delstatens BNP eller $12 \%$ av delstatens budget. Detta motsvarade delstatens utgifter för all utbildning eller dubbelt så mycket som dess hälsovårdsbudget (Srivastava \& Rehman 2006: 646).

\section{Liberalisering på 9o-talet}

Den ekonomiska liberaliseringen sedan början av 1990-talet har även påverkat landets energiförsörjning. Avreglering och privatisering av energi- och elmarknader har skett runt hela världen de senaste 10 till 15 åren. Men de statliga aktörerna dominerar fortfarande mycket starkt i Indien (se tabell 5).

Reformerna eller liberaliseringen på 9o-talet innebar framför allt att man delade upp de delstatliga State Electricity Boards i olika bolag för produktion, kraftöverföring och distribution. Vidare tillät man privata investeringar, både indiska och utländska, framför allt i produktionsledet. För det tredje sökte man stimulera transparens och konkurrens inom elsektorn. Till det syftet föreslog man etablerandet av en oberoende nationell regleringsmyndighet.

En bakgrund till avreglering och delvis privatisering av elsektorn från början av 9o-talet var de stora ekonomiska förluster de delstatliga State Electricity Boards gjorde. Beräkningar säger att dessa år 1990/91 förlorade 40 miljarder rupier, eller 6,5 miljarder svenska kronor. Endast ca $75 \%$ av kostnaderna för elproduktionen lyckades man få betalt för (Sharma et al. 2005: 565). År 2001-2002 hade förlusterna vuxit till över US \$ 6 miljarder (ibid.:570). De viktigaste förklaringarna till dessa förluster eller underskott verkar vara stöld och subsidier (Tongia 2003: 10, 19f, Katiyar 2005, Singh 2006). Stöld av elektricitet handlar till en del om familjer som på olika sätt kopplar in sig på elnätet utan att betala. Men den mer avgörande delen

\section{Tabell 5. Elektricitet: Fördelning mellan statliga och privata aktörer i procent, 2003}

\begin{tabular}{r|c|c|c} 
& Centralregeringen & Delstatsregeringar & Privata sektorn \\
\hline Elproduktion & 30 & 59 & 11 \\
Kraftöverföring & 15 & 85 & 0.4 \\
Distribution & 0 & 88 & 12
\end{tabular}

Källa: Thakur et al. (2006) 
hänför sig till företag - eller, faktiskt, regeringsorgan - som låter bli att betala elräkningen, ibland med politiskt beskydd. Mig veterligen finns ingen systematisk studie av dessa stölder, av lättförklarliga skäl förmodligen. Tyvärr har dessa reformer inte påverkat förlusterna i kraftöverföring och distribution (se Sharma et al. 2005: 572 för uppgifter för fem reformerade delstater). Och tveksamheten till privatiseringarna är utbredd i Indien. En undersökning i Delhi visade att en majoritet (54\%) ansåg att privatiseringen inte förbättrat situationen (Lal 2005: 655).

Energi tillhör «2the concurrent list» enligt den indiska konstitutionen. Med andra ord ligger ansvaret både på den centrala regeringen i New Delhi och regeringarna i de 35 delstaterna och «union territories». Den indiska Planeringskommissionen har det huvudsakliga planeringsansvaret, men energipolitiken administreras dessutom av fem olika ministerier på nationell nivå (Srivastava \& Rehman 2006: 644) - bland andra Ministry of Power, Ministry of Non-conventional Energy Sources, Department of Atomic Energy - samt ett antal myndigheter (Thakur et al. 2006):

- The Central Electricity Authority

- The National Thermal Power Corporation (1975)

- The National Hydro Power Corporation (1975)

- The Power Finance Corporation (1986)

- The Power Grid Corporation of India Ltd (1989)

- The Power Trading Corporation of India Ltd (1999)

- The Central Electricity Regulatory Commission, CERC (1999)

- The National Power Training Institute

- The Energy Management Center (1989)

Det krävs ingen fantasi för att förstå att denna situation kan skapa koordineringsproblem och rivalitet mellan olika administrationer.

År 2003 antog det indiska parlamentet en ny lag, The Electricity Act, vars syfte bland annat var elektrifiering av landsbygden, decentralisering och att låta privata aktörer eller entreprenörer på landsbygden delta i ökad utsträckning (Srivastava \& Rehman 2006: 652). På grund av regeringsskiftet året därpå, när Kongresspartiet kom tillbaka till makten, har lagen inte blivit implementerad. Denna lagstiftning nationellt föregicks av reformer i vissa delstater. Orissa i östra Indien var först år 1995. Sen följde Haryana 1997 och Andhra Pradesh, Karnataka, Rajasthan och Uttar Pradesh 1998 (Rao 2004: 156).

Enligt Thillai Rajan (2000) var det framför allt krav från Världsbanken samt den förhållandevis låga effektiviteten hos Orissas State Electricity Board som ledde till reformen. Bakom den låga effektiviteten fanns faktorer som direkt politisk inblandning i verksamheten och en brist på medvetenhet om 
kostnader och investeringsbehov (Rajan 2000). Till denna situation kom svårigheter i början av 9o-talet vid byggandet av ett större vattenkraftverk, Upper Indravati Hydro Electric Project. Världsbanken stödde projektet med \$300 miljoner men stoppade utbetalningarna när problemen uppkom och ställde krav som kulminerade i privatiseringar och höjningar av elpriset. Andra viktiga faktorer bakom dessa förändringar, eller reformer, i Orissa var enligt Rajan jordbrukets minimala roll samt en initiativkraftig ordförande i delstatens Electricity Board. Eftersom jordbrukets konsumtion av elektricitet var mycket mindre i Orissa än i många andra delstater var följaktligen jordbrukslobbyn mycket svagare och kunde inte hindra dessa förändringar.

Som antyddes i början av denna artikel är många statliga planer för framtida energiförsörjning och elektrifiering mycket ambitiösa. Ett av problemen enligt många analytiker är att det inte finns någon tydlig politisk kraft bakom dessa ord. Rejikumar (2005) kallar den National Electricity Policy från 2005 en «önskelista». Energiministeriet i Delhi formulerar mål men skickar uppgifterna och svårigheterna att genomföra policyn vidare till delstaterna. Målen i den sjunde, åttonde och nionde femårsplanen (1985-2002) var tillförsel av ytterligare ca $20.000,30.000$ respektive $40.000 \mathrm{MW}$ per femårsperiod (ibid). Den faktiska ökningen per femårsperiod blev knappt 20.000 MW (ibid). Målsättningen i den elfte femårsplanen, 2007-2012, är en ökning med 60.000 MW. Sumir Lal från Världsbanken konstaterar att en aldrig så riktig teknokratisk lösning räcker inte för att ett reformprogram ska fungera (Lal 2005: 655). Han menar att de indiska reformerna på energiområdet har misslyckats eller varit ofullständiga i viktiga avseenden därför att man dels inte lyckats skapa trovärdighet gentemot elkonsumenterna att reformerna skulle gynna dem, och dels inte lyckats bygga en tillräckligt stor och stark politisk koalition bakom förändringarna. Lal menar att många inom det civila samhället i Indien stödjer den delen av reformerna som innebär att energiförsörjningen ska lyftas bort från politiskt inflytande och patronage. Men han citerar Jayprakash Narayan som menar att «det är inte övertygande att kräva av en bybo att han ska vara med och betala underskotten i de statliga elbolagen när hela systemet är så korrupt».

En övergripande tankefigur för att förstå energipolitik i Indien är att beskriva det politiska centrum som svagt. Nu är det långtifrån svagt $\mathrm{i}$ alla avseenden. Men inom många policyområden är det svagt - både nationellt och delstatligt - i betydelsen att åstadkomma en politisk vilja och att genomföra den. Yogendra Yadav har formulerat det så att nyckeln till att förstå indiska politiker är att de talar till två offentligheter, eller publiker: dels till eliten både inom och utanför Indien, dels till deras väljare (Lal 2005). Och sättet många gånger för indiska politiker att få stöd och vinna val är att bygga personliga, ofta klientelistiska, nätverk samt ställa ut löften om partikulära förmåner; dvs förmåner till den enskilde, dennes familj, by, grupp eller kast. 
Med andra ord sådan politik som vi ofta lite nedlåtande kallar populistisk. Andra delar i denna ekvation är en ofta omfattande korruption och det egna intresset hos många som arbetar inom de (stora) statliga energibolagen. För att åstadkomma förändring - en ökning av elproduktionen och andelen som kommer från förnyelsebara energikällor - räcker det alltså inte att regeringen i New Delhi eller i delstaterna proklamerar en ny politik. Väljare, politiker, byråkrater, intressegrupper måste också vara med på noterna. Ett reformprogram måste som sin främsta ingrediens ha en «förståelse för den lokala politiska ekonomin», som Sumir Lal (2005: 655) formulerar det.

\section{Demokrati och ingenjörer styrkor}

Det känns aningen beskäftigt att ställa frågan om Indien kommer att klara dessa utmaningar. Vi talar trots allt om världens näst största land och över en miljard människor som blir 15 miljoner fler varje år, dessutom om framtiden. Och så länge vi inte uppfunnit en tillförlitlig kristallkula kommer alla framtidsstudier att vara behäftade med stora osäkerheter, för att uttrycka det försiktigt. Men trots dessa varningar, låt mig ändå på basis av egen och andras forskning om Indien spekulera.

Låt oss börja med Indiens styrkor i detta sammanhang. Den allra viktigaste styrkan är Indiens demokrati och politiska öppenhet. Som ett av mycket få utvecklingsländer har Indien haft demokrati i stort sett ända sedan självständigheten från Storbritannien 1947 (undantaget är Indira Gandhis undantagstillstånd under 18 månader 1975-77). Den indiska demokratin är också meningsfull i så måtto att många (runt 60 \%) deltar i valen och regeringar både i New Delhi och i delstaterna byts ut med jämna mellanrum. Pressfriheten är också högst reell. Det är dessa faktorer som den indiskfödde ekonomen och nobelpristagaren Amartya Sen sett som de viktigaste förklaringarna till att Indien inte haft någon svältkatastrof sedan början av 1940-talet (till skillnad mot Kina), även om många miljoner indier fortfarande lider av hunger och undernäring. Och det finns goda anledningar att tro att dessa politiska omständigheter kommer att ha en positiv verkan på en annan ödesfråga - energin och klimatet. Om medborgarna som direkt erfar energibrist och klimatförändring har möjlighet att uttrycka sin oro och vrede och möjlighet att välja den styrelse man tror bäst kan bidra till en förbättring, är en viktig förutsättning på plats.

Därmed inte sagt att lösningen av energiproblemen i Indien kommer att bli lätt, långt därifrån. Trots dessa relativt sett fördelaktiga politiska förutsättningarna är problemen omfattande, för att inte säga enorma. Ett aldrig så öppet politiskt system har att brottas med fördelningsfrågor, collective-action problems och medborgarnas tillit till statens utfästelser. En anekdot kan il- 
lustrera det sistnämnda problemet. Vid ett mycket livligt och konstruktivt byrådsmöte (Gram Sabha) i delstaten Gujarat meddelade den lokale chefsadministratören att delstatens chefsminister hade utlyst ett program där han lovade elförsörjning dygnet runt till alla byar som installerade elmätare samt lovade att betala elavgiften. Byrådets snabba svar var: «Om chefsministern först ser till att leverera elektricitet 24 timmar om dygnet så lovar vi sen att betala» (från Lal 2005: 656).

En annan styrka för Indien på energiområdet är landets kvalificerade och framgångsrika kår av tekniker och forskare. Lika stort som misslyckandet hittills varit inom primärutbildningen (endast ca $60 \%$ av befolkningen kan läsa och skriva) lika stor har framgången inom vissa delar av den högre utbildningen och forskningen varit. Indiens IITs - Indian Institute of Technology - är berömda långt utanför landets gränser. När president Clinton för ett tiotal år sen ville begränsa immigrationen till USA protesterade Microsoft mot detta eftersom man var beroende av indiska ingenjörer för sin produktion.

\section{Fattigdom och mjuk stat svagheter}

När det gäller svagheterna, eller det som kan stjälpa Indiens utvecklingsansträngningar bland annat inom energi- och klimatområdet, är det speciellt två faktorer jag vill betona. Det ena är fattigdomen: de fattiga kan endera «mobiliseras» ekonomiskt och politiskt och därmed bidra starkt till en energiomvandling av landet eller som en marginaliserad grupp närmast sätta käppar i hjulet för en sådan utveckling. Det kan endera te sig självklart eller något passé att nämna fattigdomen när vi talar om Indien. När landet ligger på plats 127 på UNDPs lista över länders «human development» och har en medelinkomst på ungefär 20.000 svenska kronor om året borde ett påpekande om fattigdom vara överflödigt. Men mot denna bild av Indien finns den sedan några år gängse bilden i media av ett land i frustande utveckling; och med en ekonomisk tillväxt på nära 10 \% årligen och en stor och växande medelklass är den bilden inte felaktig. Men den är inte komplett. Utöver en gigantisk medelklass om kanske 300 miljoner finns det en fattig underklass på omkring 800 miljoner människor. Kommer denna stora grupp - större än Europas samlade befolkning - att dras med i och bli en starkare resurs i en ekonomisk och energimässig omvandling av Indien? Bortsett från den uppenbara rättvisefrågan, är detta det ena spörsmålet. Det andra kan beskrivas som ett stort socialt dilemma (eller collective-action problem): Varför skulle de fattigaste 800 miljonerna välja en energianvändning och livsstil som tar hänsyn till riskerna med klimatförändringar om inte de rikaste 300 miljonerna gör det? Med andra ord är detta samma tankefigur eller 
International (2007) gör varje år undersökningar av korruption där länder bedöms på en skala från 10 (helt utan korruption) till o (total korruption). År 2006 rankas Indien som land nummer 70 med en korruptionsgrad på 3,3 (Finland ligger överst med 9,6 och Haiti sist på plats 163 med korruptionsgrad 1,8). Bakom de förluster på nära en tredjedel av sina inkomster som State Electricity Boards gör, ligger en hel del korruption eller «kontakter». En undersökning gjord av Transparency International India (2005) hävdar att värdet av «petty corruption» i hela landet uppgår till ca 20 milliarder rupier eller ca 3,5 miljarder svenska kronor per år. Och det är ingen större skillnad mellan offentligt och privat ägda elbolag; nära tre femtedelar av hushållen som hade privata elleverantörer i den nämnda undersökningen uppfattade dessa som korrupta (ibid.). Som en person på landsbygden i Orissa berättade för mig i slutet av 9o-talet: «Tidigare betalade vi en muta till den statliga tjänstemannen från elektricitetsverket för att han inte skulle anteckna all den ström vi hade använt. Nu när de har privatiserat bolaget så betalar vi mutan till tjänstemannen från det privata elbolaget istället. Det går på ett ut.» All förändring som involverar den statliga förvaltningen kommer förr eller senare att stöta på detta institutionella problem.

Denna problematik - hur man skapar en offentlig förvaltning som efter bästa förmåga levererar primärutbildning, hälsovård, vägar, elektricitet etc - har kommit att intressera samhällsvetare allt mer de senaste åren. Den tidigare dominerande uppfattningen att detta bara hade att göra med ekonomisk utveckling har ersatts med en mycket mer öppen och prövande inställning. Tabell 6 kan illustrera problemet. I tabellen finns uppgifter för det som kanske är viktigast vid elproduktion - att hushåll får elektricitet, att förnybar energi används och att verksamheten är effektiv. Vi kan se att dessa värden varierar mellan och inom olika delstater samt att det långtifrån finns någon enkel samvariation med de genomsnittliga ekonomiska resurserna i delstaten.

Vad kan då förklara detta mönster? En förklaring ger naturligtvis inte nödvändigtvis en handlingsrekommendation, men det är ofta en bit på vägen. Två ekonomer, Timothy Besley och Robin Burgess (2002), har undersökt vad som förklarar skillnader i indiska delstaters respons på översvämningar och skördekatastrofer i form av bland annat utdelning av mat till drabbade familjer. Genom en ekonometrisk analys av data för åren 1958-92 kommer de till slutsatsen att det är konkurrens mellan politiska partier och spridning av tidningar som bäst förklarar vilka delstater som lyckades bäst med responsivitet gentemot medborgarna inom detta politikområde. Tvärtemot mångas föreställning så visar deras analys att delstatens ekonomiska utveckling inte spelade särskilt stor roll. Deras konklusion av studien är att politikerna vill bli återvalda och ju hårdare konkurrens det råder mellan olika partier och ju mer tidningars bevakning är spridd bland 
befolkningen desto mer kommer dessa politiker att anstränga sig, att vara responsiva gentemot väljarna/medborgarna.

I en intressant och omfattande analys av den lokala staten i Kina undersöker Lily Tsai (2007) vad som förklarar varför vissa landsbygdskommuner lyckas mycket bättre med att bygga vägar, skolor och vattenledningar. Likt Besley och Burgess visar hon att de ekonomiska faktorerna inte är de avgörande. Den viktiga förklaringen är istället vad Tsai kallar solidaritetsgrupper i byn. I byar där normer och nätverk är solidariska och omfattar alla - inklusive de lokala regeringstjänstemännen som därmed innesluts i och påverkas av byns normer - så levererar också den lokala staten dessa resurser, som byborna vill ha. Kanske ännu mer intressant och relevant i detta sammanhang är den indisk-amerikanske statsvetaren Anirudh Krishnas (2002) omfattande studier av ett antal byar i nordvästra Indien. Krishna kan visa att lokala aktivister eller entreprenörer tillsammans med socialt kapital - tillit och nätverk - gör att den «lokala staten» fungerar bättre. Dvs, i en omgivning av aktiva, intresserade och tillitsfulla bybor utför den lokala byråkraten, polisen eller läraren sitt arbete bättre.

\section{Klarar Indien utmaningarna?}

Indien står inför en situation där man på ett decennium kommer att behöva öka energitillgången med en tredjedel. Detta ska ske samtidigt som man är trängd av minskande globala gas- och oljetillgångar och ett tilltagande hot om klimatförändring. Kommer Indien att klara utmaningen? Det är naturligtvis omöjligt att besvara frågan med säkerhet. Men analysen ovan ger grund för att peka ut några centrala områden för indisk energipolitik. Den största andelen av landets energi kommer idag från biomassa och avfall som i en alldeles övervägande del används «traditionellt». Ju mer denna kan omvandlas på ett effektivare sätt desto mer energi kan man tillgodogöra sig. Men detta förutsätter också en socioekonomisk omvandling av Indien där även de fattigaste 800 miljonerna dras med i och får del av det ekonomiska undret som nu sker. Ett annat område är, paradoxalt nog, besparingar. Den mycket stora andel elektricitet - ca en tredjedel - som idag ingen betalar för används naturligtvis. Men det är nog ingen vild gissning att den bonde, eller storföretag eller regeringsmyndighet som har «gratis» elektricitet inte är särskilt omtänksam eller sparsam med hur mycket som används. Det tredje området är förnyelsebar energi - vind, vatten, sol och vågor. Som 
diskussionen ovan visat kommer en mycket liten andel från dessa energislag idag, knappt en procent globalt och noll procent eller knappt mätbart i Indien. Men de fysiska förutsättningarna och den tekniska kompetensen finns i Indien för att öka denna andel.

En avgörande pusselbit som avgör om miljardlandet Indien kommer att lyckas hantera energiutmaningarna kommer att vara politiken. Kommer den politiska och administrativa viljan och kapaciteten på olika nivåer - från New Delhi till byar i Tamil Nadu och Bihar - att vara tillräcklig för att veta vad man ska göra och sedan göra detta?3 Forskning gjord av Besley \& Burgess, Krishna, Tsai och andra visar på att en avgörande faktor för att få politiska resultat kan vara relationen mellan politiker och medborgare. Vilka normer och regler - vilka institutioner - präglar denna relation? Vi behöver mer kunskap och systematisk forskning inte minst om hur sådana mönster och institutioner kan förändras. Både praktiskt och teoretiskt förstår vi ganska väl varför samarbete eller konflikt i en grupp eller ett helt samhälle fortsätter; samarbetar «de andra» så samarbetar även «jag» gärna. Eller omvänt: Det tillhör inte vanligheterna att se personer bidra till det gemensamma bästa $\mathrm{i}$ en situation där ingen annan gör detta, alltifrån triviala situationer t ex i trafiken eller att spara energi till ett våldsamt inbördeskrig. Men hur sådana icke-samarbeten kan förändras till samarbeten vet vi relativt lite om och på denna punkt skulle samhällsvetare kunna bidra med central kunskap. Precis som med statens agerande vid hungerkatastrofer är det en god gissning att detta även är viktigt för att förklara skillnader (jfr tabell 6) i energianvändning och elproduktion mellan olika delstater i Indien. Och till skillnad mot mycket annat som händer i detta stora land är det högst troligt att resultatet av dessa ansträngningar kommer att påverka oss i norra Europa, och resten av världen, på ett högst påtagligt sätt.

3 Tillsammans med forskare i kognitionspsykologi, ingenjörsvetenskap och statsvetenskap vid Uppsala universitet planerar vi ett forskningsprogram - URGENT; Uppsala Research proGramme on our common ENergy fuTure - om förnybar energi och institutioner i utvecklingsländer, främst Indien och Brasilien. Kontakt: Hans.Blomkvist@statsvet.uu.se 


\section{Litteratur}

Besley, Timothy \& Robin Burgess (2002) «The political economy of government responsiveness: Theory and evidence from India», The Quarterly Journal of Economics CXVII: (1415-51).

Bhattacharyya, Subhes (2006) «Energy access problem of the poor in India», Energy Policy 34: (3387-97).

Blomkvist, Hans (1992) The Soft State: Making Policy in a Different Context» i Douglas Ashford (red.) Context and Meaning in Comparative Public Policy. Pittsburgh, PA: Univ. of Pittsburgh Press.

Blomkvist, Hans (1995) «Is the State in India Particularistic?», Forum for Development Studies 22 (2): (285-308).

Chen, Sheng-Tung ( 2007) «The relationship between GDP and electricity consumption in 10 Asian countries», Energy Policy 35: (2611-21).

Drèze, Jean \& Amartya Sen (2002) India: Development and Participation. Delhi: Oxford University Press.

EIA (Energy Information Administration) (2007) USAs Energidepartement (http://www. eia.doe.gov) nerladdat 2007-07-03.

Elias, Rebecca \& David Victor (2005) «Energy transitions in developing countries», Working Paper (40), Program on Energy and Sustainable Development, Stanford University (http://pesd.stanford.edu).

Ghosh, Debyani \& P.R. Shukla, A. Garg, P.V. Ramana (2002) «Renewable energy for the Indian power sector», Renewable and Sustainable Energy Reviews 6: (481-512).

Gulyani, Sumila (1999) «Innovating with infrastructure: How India's largest carmaker copes with poor electricity supply», World Development 27: (1749-68).

IEA (International Energy Agency) (2006a) World Energy Outlook 2006. Paris: OECD/ IEA.

IEA (International Energy Agency) (2006b) Energy Policies of IEA Countries 2006. Paris: OECD/IEA.

Kale, Sunila (2004) «Current reforms: The politics of policy change in India's electricity sector», Pacific Affairs 77: (467-91).

Katiyar, Sudhir Kumar (2005) «Political economy of electricity theft in rural areas: A case study of Rajasthan», Economic Q Political Weekly Feb: (644-48).

Kishore, Bhandari \& Gupta (2004) «Biomass energy technologies for rural infrastructure and village power», Energy Policy 32: (801-10).

Krishna, Anirudh (2002) Active Social Capital: Tracing the Roots of Development and Democracy. New York, NY: Columbia University Press.

Lal, Sumir (2005) «Can good economics ever be good politics? Case study of the power sector in India», Economic \& Political Weekly Feb: (638-43).

Mallon, Karl (red.) (2006) Renewable Energy Policy and Politics. London: Earthscan.

Mathur, Jaskiran Kaur \& Dhirai Mathur (2005) «Dark homes and smoky hearts: Rural electrification and women», Economic \& Political Weekly, Feb: (649-56).

MNES (Ministry of Non-conventional Energy Sources) (2005) «New and Renewable Energy Policy Statement», Draft.

MoP (Ministry of Power, Government of India) (2007) «Installed capacity», nedladdad från internet, 2007-03-02.

Pachauri, R.K. (2006) «Introduction» i Bhojvvaid (red.) Biofuels: Towards a greener and secure energy future. New Delhi: TERI Press. 
Rao, S. L. (2004) Governing Power. New Delhi: TERI.

Rajan, Thillai (2000) «Power sector reform in Orissa», Energy Policy 28: (657-69).

Rejikumar, R. (2005) «National electricity policy and plan: A critical examination», Economic Q Political Weekly May: (2028-32).

Sagar, Ambuj \& Sivan Kartha (2007) «Bioenergy and sustainable development?», Annual Review of Environmental Resources 32: (131-67).

Sharma, Parameswara \& Nair \& Balasubramaniam (2005) «Performance of Indian power sector during a decade under restructuring», Energy Policy 33: (563-76).

Singh, Anoop (2006) «Power sector reform in India», Energy Policy 34: (2480-90).

Srivastava \& Rehman (2006) «Energy for sustainable development in India», Energy Policy 34: (643-54).

TEDDY, Teri Energy Data Directory Q Y Yearbook 2004/05. New Delhi: The Energy and Resources Institute.

Thakur, Tripta (2006) «Efficiency evaluation of the state owned electric utilities in India», Energy Policy 34: (2788-04).

Tongia, Rahul (2003) «The political economy of Indian power reforms», Working Paper (4), Program on Energy and Sustainable Development, Stanford University (http:// pesd.stanford.edu).

Transparency International (2007) Corruption Perception Index (http://www.transparency. org/).

Transparency International India (2005) India Corruption Study to Improve Governance (http://www.tiindia.in).

Tsai, Lily (2007) «Solidary groups, informal accountability, and local public goods provision in rural China», American Political Science Review 101: (355-72). 